\title{
DETERMINANT FACTORS TO THE EXISTENCE OF AEDES AEGYPTI MOSQUITO IN THE WORKING AREA OF UBUD I HEALTH CENTER GIANYAR REGENCY, BALI
}

\author{
Kadek Risma Yulina Sari \\ Department of Environment, \\ Faculty of Public Health, Airlangga University, Surabaya, Indonesia \\ Correspondence Address: Kadek Risma Yulina Sari \\ E-mail: Kadek.Risma.Yulina-2015@fkm.unair.ac.id
}

\begin{abstract}
Ubud I Primary Healthcare Center's working area showed an annual increase in dengue hemorrhagic fever (DHF) cases and deaths. It reported the highest DHF cases out of 13 Primary Healthcare Centers in Gianyar district. The purpose of this study was to analyze the determinants of the Aedes aegypti larvae' existence in the Ubud I Primary Healthcare Center 's working area, Gianyar district, Bali. This research was an analytic observational study with a cross-sectional study design. The research sample was 95 respondents chosen randomly using the simple random sampling technique. The high DHF cases in the Ubud I Primary Healthcare Center working area can be referred to environmental factors and community behavior factors. Interviews, larvae observation and other observations were done to collect data. Chi-square statistical test was used for data analysis. The results showed that there was a relationship between the MNE-DHF actions $(\mathrm{p}=0.047)$, water PH ( $\mathrm{p}=0.001)$, container color $(\mathrm{p}=0,000)$ to Aedes aegypti larvae' presence. On the other hand, MNE-DHF knowledge $(\mathrm{p}=1.00)$ and room humidity $(\mathrm{p}=0.357)$ showed no relationship with Aedes aegypti larvae' presence. Thus, it has been concluded that community actions, container color, and water $\mathrm{pH}$ have significant relationships with the larvae' existence. It is recommended to increase community awareness of applying more environmental management precautions.
\end{abstract}

Keywords: Container's Color, Dengue Fever, Aedes aegypti

\begin{abstract}
ABSTRAK
Pada wilayah kerja Puskesmas Ubud I, selalu terjadi peningkatan kasus DBD setiap tahunnya dan setiap tahun pula terdapat kematian akibat DBD. Puskesmas Ubud I memiliki kasus DBD paling tinggi dari 13 puskesmas di Kabupaten Gianyar. Tujuan penelitian ini adalah untuk menganalisis faktor determinan keberadaan jentik Aedes aegypti di wilayah kerja Puskesmas Ubud I, Kabupaten Gianyar, Bali. Penelitian ini bersifat observasional analitik dengan desain potong lintang. Sampel penelitian sebesar 95 orang yang diambil secara acak menggunakan teknik sampling acak sederhana. Tingginya kasus DBD masyarakat di wilayah kerja Puskesmas Ubud I diduga karena beberapa faktor lingkungan dan faktor perilaku masyarakat. Wawancara, observasi, dan pengamatan jentik dilakukan secara visual untuk mendapatkan variabel yang diteliti. Analisi data yang digunakan adalah uji statistik Chi-square. Hasil penelitian menunjukan terdapat hubungan antara tindakan PSN DBD ( $p=0,047)$, pH air ( $p=0,001)$, warna kontainer $(p=0,000)$ terhadap keberadaan jentik Aedes aegypti. Sedangkan, tidak ada hubungan antara pengetahuan PSN DBD $(p=1,00)$ dan kelembapan ruangan ( $p=0,357)$ dengan keberadaan jentik Aedes aegypti. Penelitian ini menyimpulkan tindakan masyarakat, warna kontainer, dan pH air memiliki hubungan yang signifikan terhadap keberadaan jentik. Penelitian ini menyarankan puskesmas untuk lebih meningkatkan kesadaran dari masyarakat untuk melakukan manajemen lingkungan.
\end{abstract}

Kata Kunci: Warna Kontainer, Demam Berdarah Dengue, Aedes aegypt

\section{INTRODUCTION}

Dengue hemorrhagic fever (DHF) is an indirect mosquito-borne infectious disease. The vectors of infectious DHF are Aedes aegypti, Aedes Scutellaris complex, Aedes Albopictus, and Aedes Polynesiensis. However, Aedes aegypti mosquito is considered the first vector responsible for DHF transmission among all vectors. Children under 15 years are the most vulnerable to DHF than others. DHF is associated with some symptoms including high fever, headache, skin rashes, and joints pain. In advanced conditions, DHF can cause a failure which 
can trigger Dengue Shock Syndrome (DSS) and lead to death (World Health Organization, 2009).

Urban areas population has a higher DHF risk, especially in tropical and subtropical countries (World Health Organization, 2009) including Indonesia which reported a persistent increase in DHF cases. Indonesia recorded the secondhighest dengue cases among other $30 \mathrm{DHF}$ endemic countries (Indonesian Ministry of Health, 2017).

The first DHF case in Indonesia was recorded in 1968 in Surabaya city which reported 58 cases including 24 deaths. After that, DHF cases have increased affecting all regions in Indonesia except areas of altitude more than 1000 meters above sea level. Generally, factors that influence DHF include environmental conditions, population density, natural or artificial water reservoirs, counseling, and community behavior related to the Mosquito Nest Eradication of dengue hemorrhagic fever (MNE-DHF) or pemberantasan sarang nyamuk demam berdarah dengue (PSN DBD) (Indonesian Ministry of Health, 2001).

DHF cases in Indonesia increased from 2014 to 2016. However, starting from 2017, DHF cases started to decrease. In 2016 the total of cases was 204,171 cases and it decreased to 68,407 cases in 2017 then it reduced again to 65,602 cases in 2018. However, despite the decline in DHF cases, Angka Bebas Jentik (ABJ) to larva free rate has not reached yet the Indonesian national standard since the rate is still below 95\% (Indonesian Ministry of Health, 2018).

The DHF incidence rate (IR) in Bali province increased from 2013 to 2016 due to the favorable breeding environment for mosquitoes (Indonesian Ministry of Health, 2016). In 2017, the DHF incidence rate in Bali Province decreased, compared to 2016 in IR which was 515.90 per 100,000 population, to 107.5 per 100,000 population then it declined again to 21.06 per 100,000 population in 2018 . Therefore,
Bali Province has met the IR national target of less than 49 per 100,000 population (Indonesian Ministry of Health, 2018).

Gianyar district is the $2^{\text {nd }}$ highest geographically with the highest DHF incidence rate in Bali province. DHF cases continued to grow from 2013 to 2016. However, cases declined from 3,673 cases in 2016 to 511 cases in 2017 and reached 72 cases in 2018. Despite the decline in cases, larva free rate in Gianyar district has not reached the Indonesian national standard of being more than $95 \%$ (Indonesian Ministry of Health, 2017).

DHF cases that occurred in the Ubud I Primary Healthcare Center 's working area in Gianyar district have increased from 2014 to 2016. However, from 2017 to 2018 DHF cases in the working area have decreased. In 2014 there were 535 DHF cases, in 2015 there were 507 cases, in 2016 there were 696 cases, in 2017 there were 112 cases and in 2018 DHF cases dropped dramatically to 12 cases. Despite the persistent decline in DHF cases in the Ubud I Primary Healthcare Center in Gianyar district, it recorded the highest DHF incidence rate out of the 13 public health centers in Gianyar district ( Gianyar Regency Health Office, 2017).

Aedes aegypti larvae' presence in the surrounding environment which is known as larva free rate is considered the DHF transmission indicator: the higher the larva free rate, the lower the DHF transmission risk while the lower the larva free rate, the higher the DHF transmission risk (Malasari, 2011).

DHF onset is referred to many factors including environmental, host, and viral factors (Chandra, 2005). Environmental and host factors are the main disease transmission factors. Environmental factors such as optimal humidity, waterlogging, and optimal water $\mathrm{pH}$ can create a favorable nourishing and breeding environment for mosquitoes. Furthermore, host factors such as the habit 
of hanging clothes outside the cupboard, uncommon water reservoirs' cleaning, keeping trash cans opened can support the mosquitoes' presence in the environment. The favorable environment and bad behavior related to MNE-DHF can increase the risk of DHF transmission by Aedes aegypti mosquitoes (Sumantri, 2010). Thus, efforts to control these factors are a necessity to prevent the vectors from spreading in the environment (Indonesian Ministry of Health, 2010).

The environmental and host factors are also responsible for the occurrence of DHF cases in the Ubud I Primary Healthcare Center's working area in Ginayar district, Bali. Therefore, the purpose of this research is to analyze the factors associated with the presence of Aedes aegypti larvae which is the main vector in transmitting DHF.

\section{METHODS}

The research was analytic and observational with a cross-sectional research design analyzing independent and dependent variables simultaneously. Respondents were interviewed using a questionnaire while the respondents' houses were checked to determine the water $\mathrm{pH}$, the humidity by observing the container color, and the Aedes aegypt lavae' presence using an environmental observation sheet which met the larvae observation sheet standard provided by the health minister (Indonesian Ministry of Health,2016).

This research was conducted in Ubud I Primary Healthcare Center's working area, Gianyar district, Bali since it recorded the highest annual DHF cases among 13 Health Centers in Gianyar district. The research was done from May 2019 to June 2019. Sample size has been calculated using the Lameshow and David formula (1997) as follows:

$$
\mathrm{n}=\frac{z_{1}^{2}-\frac{\alpha}{2} P(1-P) N}{d^{2}(N-1)+z_{1}^{2}-\frac{\alpha}{2} P(1-P)}
$$

$$
\begin{aligned}
& \text { Notes: } \\
& \mathrm{n}=\text { Number of samples in the } \\
& \begin{aligned}
z_{1}^{2}-\frac{\alpha}{2}== & \begin{array}{l}
\text { Normal distribution value } \\
(\text { Table } \mathrm{Z})
\end{array}
\end{aligned} \\
& \mathrm{P} \quad=\text { Proportion value in the } \\
& \text { population } \\
& \text { D }=\text { Tolerable limit error }
\end{aligned}
$$

According to the formula above, a total sample of 95 houses and their householders' heads were selected by the researchers. The sample was taken from the highest DHF cases hamlet in each village in the Ubud I Public Health Center's working area in Gianyar district, Bali. The sample was collected using a simple random sampling technique. Thus, each householder's head had the same opportunity to be a respondent. Before sampling, a list of families' heads was collected then compiled used the sampling frame.

Interviews were conducted using a questionnaire to the householder head or another family member in the observed house. The questionnaire was about the respondents' knowledge and behavior related to MNE-DHF. The purpose of the environmental observation was to notice the presence or absence of larvae in the environment visually and recorded it in the survey.

The independent variables in this study were knowledge about MNE-DHF, the action of MNE-DHF, water $\mathrm{pH}$, room humidity, and humidity container color while the dependent variable was the Aedes aegypti larvae' existence in the Ubud I Public Health Center's working area.

Knowledge about MNE-DHF was categorized as good (score 76\% -100\%), moderate (score $56 \%-75 \%$ ), and poor (score less than 56\%). Action of MNEDHF was categorized as good (score $76 \%$ $100 \%$ ), moderate (score $56 \%-75 \%$ ), and 
poor (score less than $56 \%$ ). Water $\mathrm{pH}$ was categorized as optimal (7-11), and nonoptimal (less than 7 or more than 11). Humidity container color was categorized as dark (brick red, black, green, blue) and light (white, yellow, orange, pink). Room humidity was categorized as optimal $(60 \%$ $-80 \%$ ) and non-optimal (less than $60 \%$ or more than $80 \%$ ). Larvae' existence was classified as existed or non existed.

The analysis was performed using bivariate and Chi-square statistical tests to determine the relationship between all independent variables with the dependent variable. The study ethical approval certificate with the number 133 / EA / KEPK / 2019 was obtained on $30^{\text {th }}$ April 2019 by the Ethics Commission of Public Health Faculty, Airlangga University.

\section{RESULT}

The research results of 95 houses and householder's heads in the Ubud I Primary Healthcare Center's working area using univariate and bivariate statistical tests for the variables of MNE-DHF knowledge, MNE-DHF action, water $\mathrm{pH}$, room humidity, and color of humidity container, were as follows.

Table 1. Distribution of respondents' knowledge about MNE-DHF in the Ubud I Primary Healthcare Center's working area

\begin{tabular}{ccc}
\hline Knowledge & $\mathbf{N}$ & $\mathbf{\%}$ \\
\hline Poor & 1 & 1.1 \\
Intermediate & 10 & 10.5 \\
Good & 84 & 88.4 \\
\hline Total & 95 & 100 \\
\hline
\end{tabular}

The distribution of respondents' knowledge about MNE-DHF is presented in Table 1. Table 1 shows that $88.4 \%$ of respondents had good knowledge, $10.5 \%$ had moderate knowledge, and $1.1 \%$ had poor knowledge about MNE-DHF. Thus, most respondents of this study had good knowledge about MNE-DHF.

Table 2. Distribution of respondents' actions of MNE-DHF in the Ubud I Primary Healthcare Center's working area

\begin{tabular}{ccc}
\hline Knowledge & $\mathbf{N}$ & $\mathbf{\%}$ \\
\hline Poor & 57 & 60 \\
Intermediate & 16 & 16.8 \\
Good & 22 & 23.2 \\
\hline Total & 95 & 100 \\
\hline
\end{tabular}

The distribution of respondents' actions of MNE-DHF in the Ubud I Primary Healthcare Center's working area is demonstrated in Table 2. Table 2 presents that $23.2 \%$ of respondents had good actions, $16.8 \%$ had moderate actions and $60.0 \%$ had poor actions of MNE-DHF. Thus, most respondents of this study had unfavorable actions of MNE-DHF.

Table 3. Water $\mathrm{pH}$ distribution in the Ubud I Primary Healthcare Center's working area

\begin{tabular}{ccc}
\hline pH of Water & $\mathbf{N}$ & $\mathbf{\%}$ \\
\hline Not optimum & 110 & 40.6 \\
Optimum & 161 & 59.4 \\
\hline Total & 271 & 100 \\
\hline
\end{tabular}

The water $\mathrm{pH}$ distribution is presented in Table 3. Table 3 manifests that the 95 observed houses contained a total of 271 containers. It displays that $59.4 \%$ of containers had optimal water $\mathrm{pH}$ as a favorable breeding environment for Aedes aegypti larvae, while $40.6 \%$ of containers had non-optimal water $\mathrm{pH}$ for the larvae breeding. Therefore, most of the respondents' observed houses had optimal water $\mathrm{pH}$ for larvae breeding. 
Table 4. Distribution of respondents' humidity container color in the Ubud I Primary Healthcare Center's working area

\begin{tabular}{ccc}
\hline Container Color & $\mathbf{N}$ & \% \\
\hline Dark & 77 & 28 \\
Light & 194 & 72 \\
\hline Total & 271 & 100 \\
\hline
\end{tabular}

The distribution of humidity container color is presented in Table 4. The color of 271 containers of 95 respondents observed houses was examined. Findings showed that $72 \%$ of containers were categorized as light color containers while $28 \%$ of them were classified as dark color containers. It can be concluded that the majority of respondents' containers in the study area were light-colored.
Table 5. Room humidity distribution in the Ubud I Primary Healthcare Center's working area

\begin{tabular}{lcc}
\hline $\begin{array}{l}\text { Room } \\
\text { Humidity }\end{array}$ & n & $\%$ \\
\hline Not Optimum & 39 & 41.1 \\
Optimum & 56 & 58.9 \\
\hline Total & 95 & 100 \\
\hline The room humidity distribution is \\
demonstrated in Table 5. The study \\
observed 95 respondents' rooms to check \\
their humidity. The results presented that \\
41.1\% of rooms had non-optimal humidity \\
for the Aedes aegypti larvae breeding, \\
while 58.9\% of rooms had optimal \\
humidity for its breeding. It can be inferred \\
that most of the study's observed rooms \\
had optimal humidity for Aedes aegypti \\
mosquito breeding.
\end{tabular}

Tabel 6. Relationship between the determinant factors and the existence of Aedes aegypti larvae in the Ubud I Primary Healthcare Center's working area, Gianyar district, Bali

\begin{tabular}{|c|c|c|c|c|c|c|c|c|}
\hline \multirow{3}{*}{ Variable } & \multirow{3}{*}{ Category } & \multicolumn{6}{|c|}{ The Aedes aegypti larva presence } & \multirow{3}{*}{$\begin{array}{c}\text { p- } \\
\text { value }\end{array}$} \\
\hline & & \multicolumn{2}{|c|}{ Existed } & \multicolumn{2}{|c|}{ Not existed } & \multicolumn{2}{|c|}{ Total } & \\
\hline & & $\mathbf{f}$ & $\%$ & $\mathbf{f}$ & $\%$ & $\mathbf{f}$ & $\%$ & \\
\hline \multirow[t]{2}{*}{ Knowledge } & Moderate & 3 & 3.2 & 8 & 8.4 & 11 & 11.6 & \multirow[b]{2}{*}{1.00} \\
\hline & Good & 24 & 25.3 & 60 & 63.2 & 84 & 88.4 & \\
\hline \multirow[t]{3}{*}{ Action } & Poor & 21 & 22.1 & 36 & 37.9 & 57 & 60.0 & \multirow{3}{*}{0.047} \\
\hline & Moderate & 4 & 4.2 & 12 & 12.6 & 16 & 16.8 & \\
\hline & Good & 2 & 2.1 & 20 & 21.1 & 22 & 23.2 & \\
\hline Water $\mathrm{pH}$ & Non-optimal & 32 & 11.8 & 129 & 47.6 & 161 & 59.4 & \\
\hline
\end{tabular}

\begin{tabular}{ccccccccc}
\hline & Optimal & 6 & 2.2 & 104 & 38.4 & 110 & 40.6 & \\
\hline $\begin{array}{c}\text { Container } \\
\text { color }\end{array}$ & Dark & 9 & 3.3 & 185 & 68.3 & 194 & 71.6 & 0.000 \\
\cline { 1 - 6 } & Light & 29 & 10.7 & 48 & 17.7 & 77 & 28.4 & \\
\hline $\begin{array}{c}\text { Room } \\
\text { humidity }\end{array}$ & Non optimal & 13 & 13.7 & 43 & 45.3 & 56 & 59 & 0.536 \\
\cline { 1 - 5 } & Optimal & 7 & 7.4 & 32 & 33.7 & 39 & 41 & \\
\hline
\end{tabular}

The relationship between the knowledge about MNE-DHF and Aedes aegypti larvae' presence is demonstrated in Table 6. The table shows that respondents with good knowledge were more likely to have larvae in their houses with a percentage of $25.3 \%$ while others with moderate knowledge (only 3 respondents) had larvae in their houses with a percentage of $3.2 \%$. The p-value according to Chi-square statistical test was 1.00 . Since the p-value was greater than 0.05 , it 
can be inferred that there was no relationship between respondents' knowledge about MNE-DHF and the presence of Aedes aegypti larvae in the Ubud I Primary Healthcare Center's working area.

The relationship between the actions of MNE-DHF and Aedes aegypti larvae' existence is presented in Table 6. The table shows that respondents with poor actions were more likely to have larvae in their houses with a percentage of $22.1 \%$ while others with moderate actions (4 respondents) had larvae in their houses with a percentage of $4.2 \%$ and respondents with good actions (only 2 respondents) had larvae in their houses with a percentage of $2.1 \%$. The $\mathrm{p}$-value according to Chi-square statistical test was 0.047 . Since the p-value was smaller than 0.05 , it can be concluded that there was a relationship between respondent action of MNE-DHF and the Aedes aegypti larvae' existence in the respondents' house environment.

The interview survey results using a questionnaire showed that respondents' knowledge about MNE-DHF in the Ubud I Primary Healthcare Center's working area, Gianyar district, Bali was mostly good. This can be referred to the positive and supportive response of the participants. However, the respondents showed poor actions of MNE-DHF approved by the Aedes aegypti larvae' presence in their house environments such as bathtub, toilet, bucket, and barrel. Interview questionnaire results showed that most respondents rarely follow the MNE-DHF required measures as covering water containers, draining water containers at least 1 time per week, and putting clothes inside the cupboard. The respondents' poor actions may refer to the lack of public awareness about MNE-DHF required measures needed to control dengue disease transmission.

The relationship between the water $\mathrm{pH}$ and Aedes aegypti larvae' existence is presented in Table 6 . Table 6 displays that containers with optimal water $\mathrm{pH}(32$ containers) were more likely to have larvae with a percentage of $11.8 \%$ while containers with non-optimal water $\mathrm{pH}$ (6 containers) had larvae with a percentage of $2.2 \%$. The p-value according to Chi-square statistical test was 0.001 . Since the p-value was smaller than 0.05 , it can be concluded that there was a significant relationship between water $\mathrm{pH}$ and the existence of Aedes aegypti larvae in the Ubud I Primary Healthcare Center's working area. The survey results found that the average optimal water $\mathrm{pH}$ for Aedes aegypti larvae' existence in respondents' containers was (6.8-8.0).

The relationship between the container color and Aedes aegypti larvae' existence is presented in Table 6 . The table shows that containers with darker colors $(9$ containers) had more probability of larvae' existence with a percentage of $10.7 \%$ while light containers ( 7 containers) showed larvae' existence with a percentage of $3.3 \%$. The p-value according to Chi-square statistical test was 0,000 . Since the p-value was smaller than 0.05 , it can be concluded that there was a significant relationship between container color and the existence of Aedes aegypti larvae in the Ubud I Primary Healthcare Center's working area. The survey results found that most respondents' containers had white, pink and light blue colors.

The relationship between the room humidity and Aedes aegypti larvae' existence is shown in Table 6. The table presents that rooms with optimal humidity had more probability of larvae' existence with a percentage of $13.68 \%$ while rooms with non-optimal humidity (7 containers) showed larvae' existence with a percentage of $7.37 \%$. The p-value according to Chisquare statistical test was 0.536 . Since the $\mathrm{p}$-value was greater than 0.05 , it can be concluded that there was no relationship between room humidity and the existence of Aedes aegypti larvae in the Ubud I Primary Healthcare Center's working area which had a closed environment with poor ventilation and low sun exposure. 


\section{DISCUSSION}

\section{Relationship between Community Knowledge about PSN BDB and Aedes aegypti larvae existence}

According to Chi-square statistical test score ( $p$-value $=1.00$ ), it can be stated that there was no relationship between community knowledge about MNE-DHF and the presence of Aedes aegypti larvae in the Ubud I Primary Healthcare Center's working area. The interview survey results using a questionnaire showed that respondents' knowledge was mostly good. This is because health workers of Ubud I Primary Healthcare Center's working area had previously educated the respondents about MNE-DHF. However, even though respondents had good knowledge, respondents' houses environment, including bathtub, toilet, bucket, and barrel, showed a presence of Aedes aegypti larvae. This can be referred to that most respondents did not strictly follow the MNE-DHF required measures as covering water containers, draining water containers at least 1 time per week, and putting clothes inside the cupboard.

Similarly, Bestari and Siahaan (2018) affirmed that there was no relationship between the knowledge about MNE-DHF and the larvae' existence in the environment. In other words, good respondents' knowledge is not a certain indicator for having free larvae environment since other factors can play role in larvae' existence including poor facilities and infrastructure in addition to an unfavorable human environment. For instance, open trash cans and uncovered water reservoirs, as have seen in the environmental observations, can provide an advantageous environment for larvae' breeding.

\section{Relationship between Community Actions of BDB PSN and Aedes aegypti larvae existence}

According to Chi-square statistical test score $(\mathrm{p}$-value $=0.047)$, it can be stated that there was a relationship between community actions of MNE-DHF and the presence of Aedes aegypti larvae in the Ubud I Primary Healthcare Center's working area. The interview survey results using a questionnaire showed that most of the respondents had poor actions as to not drain water containers regularly, to keep clothes outside the cupboard, to not cover water containers in addition to uncommon Urbanization.

Nani (2017) also asserted that there was no relationship between the actions of MNE-DHF with the presence of Aedes aegypti larvae with a PR value of 3.89 and $95 \%$ CI (2.01-7.52). It means that respondents with poor actions of MNEDHF had a probability of larvae' presence in their environment 3.89 times more than respondents with good actions. Furthermore, Budiman (2016), similarly, stated that there was a relationship between actions of MNE-DHF and larvae' existence in the environment. putting clothes inside the cupboard, not cleaning water-filled containers, and not covering water reservoirs can promote the larvae' existence in the environment.

In brief, poor actions can provide an excellent Aedes aegypti breeding environment, especially in water containers. Therefore, it is crucial to enhance good community actions of MNEDHF such as cleaning and draining water containers at least once a week. Furthermore, community counseling and training to enhance public awareness about the required measures of MNE-DHF is a necessity since the good community actions of MNE-DHF can dramatically reduce the DHF transmission in the Ubud I Primary Healthcare Center's working area (Indonesian Ministry of Health 2017).

\section{Relationship between water $\mathrm{pH}$ and Aedes aegypti larvae existence}

According to Chi-square statistical test $\operatorname{score}(p$-value $=0.001)$, it can be stated that there was a relationship between water $\mathrm{pH}$ and the presence of 
Aedes aegypti larvae in the Ubud I Primary Healthcare Center's working area. The environmental observations results conducted on the working area of the Ubud I Health Center showed that the optimal $\mathrm{pH}$ for Aedes aegypti larvae breeding was 6.8 to 8.0. Water $\mathrm{pH}$ affects larvae' existence by influencing their survival or growth since acidic water $\mathrm{pH}$ ( less than 3 ) and very alkaline $\mathrm{pH}$ (over 12) can interfere with Aedes aegypti larvae' development to adult mosquitoes (Jacob, Pijoh dan Wahongan, 2014).

Janah and Pawenang (2017) also confirmed the previous findings by showing a relationship between well water $\mathrm{pH}$ and the presence of Aedes aegypti larvae. Furthermore, Maftukhah, Azam and Azinar (2017) similarly correlated between water $\mathrm{pH}$ and the Aedes aegypti larvae' presence. The average water $\mathrm{pH}$ for Aedes aegypti larvae' breeding, in which hatching eggs are developed to larvae, is 7 to 11 .

To control Aedes aegypti larvae existence related to water $\mathrm{pH}$, environmental management efforts should be applied including cleaning and draining water containers at least once a week, keeping clothes in the closet, installing gauze in the vents to repel mosquitoes from houses, covering trash cans, and maintaining the surrounding environment cleanliness. These efforts can prevent Aedes aegypti mosquitoes to find favorite spots to stay and breed. However, the community itself should check Aedes aegypti larvae existence independently using a flashlight to prevent mosquitoes from breeding in the environment (World Health Organization, 2011).

\section{Relationship between container color and Aedes aegypti larvae' existence}

According to Chi-square statistical test $\operatorname{score}(p$-value $=0.000)$, it can be concluded that there was a relationship between container color and the presence of Aedes aegypti larvae in the Ubud I Public Health Center's working area. The environmental observations results conducted on the working area of the Ubud I Health Center showed that most larvaecontained water containers were dark in color due to the poor water cleaning or drainage. The dark-colored water containers attract Aedes aegypti larvae as they feel safe to lay and produce more eggs. Furthermore, the dark-colored water containers can absorb heat easily attracting Aedes aegypti mosquitoes to breed in it. However, surfaces of containers with a high amount of water can also appear darker, making the Aedes aegypti mosquito feel safe and comfortable to breed (Nurjana dan Kurniawan, 2017).

Gafur and Jastam (2015) also asserted that there was a relationship between the containers' color and larvae' existence in the environment. The study conducted on Motu Village, Baras subdistrict, North Mamuju district showed that most of the larvae positive containers (90.4\%.) were dark.

To control Aedes aegypti larvae' existence related to container color, environmental management activities should be applied including urbanization, water cleaning and draining containers routinely at least once a week, and covering water reservoirs. These measures aim to lower the possibilities of larvae' breeding, especially in daily used water containers. However, the community itself, especially in the Ubud I Primary Healthcare Center's working area, should take some precautions such as using mosquito nets, putting mosquito nets in ventilation, and using anti-mosquito lotion to avoid human mosquitoes contact (Indonesian Ministry of Health, 2016).

\section{Relationship between room humidity and Aedes aegypti larvae' existence}

According to Chi-square statistical test $\operatorname{score}(p$-value $=0.536)$, it can be concluded that there was a relationship between container color and the presence of Aedes aegypti larvae in the Ubud I Primary Healthcare Center's working area. The environmental observations results 
showed that humidity in most respondents' rooms was optimal and high enough to create an excellent breeding ground for Aedes aegypti larvae. This is because rooms were closed most of the time in addition to having low ventilation and less sun lighting. In general, the increase of room humidity can be a result of low wind movement or less sunlight besides closed room. As a consequence, high humidity rooms can attract mosquitoes to breed in their containers. The optimal humidity for mosquitoes to breed is $60 \%$ to $80 \%$ (Cahyono, 2017).

In parallel to this study findings, a study by Wijirahayu and Sukesi (2019) stated that there was no relationship between room humidity and the Aedes aegypti larvae presence $(\mathrm{p}$-value $=0.642$ ) That study showed that room humidity was caused by two factors: low altitude of the study area the respondents' habit of keeping doors and windows unclosed from morning until noon causing a change in the room atmosphere level.

However, the results recorded Aedes aegypti larvae' presence even in water containers of non-optimal humidity rooms in the Ubud I Health Center working area. This can be referred to the anthropophilic properties of Aedes aegypti mosquitoes. Anthropophily is a mosquito trait to prefer being close to humans since mosquitoes need to feed on human blood needed to mature their eggs even in an unfavorable breeding environment with not optimal humidity. Therefore, the community should take many precautions as using mosquito nets, using antimosquito lotion, using anti-mosquito gauze to avoid humans mosquito contact in addition to maintaining environmental cleanness to prevent mosquito breeding (Dinata, 2018).

\section{CONCLUSION}

In Ubud I Primary Healthcare Center's working area in Gianyar Regency, Bali, most of the respondents had good knowledge about MNE-DHF. However, the majority of respondents showed poor actions of PSN DBD. The water $\mathrm{pH}$ of the environment was mostly in the optimum category. While most water containers were light-colored.

This study showed that respondents' actions of MNE-DHF, water $\mathrm{pH}$, and container color have a significant relationship with Aedes aegypti larvae' presence in the Ubud I Health Center's working area, Gianyar district, Bali. On the other hand, respondents' knowledge about MNE-DHF and room humidity has no relationship with Aedes aegypti larvae' existence in the Ubud I Health Center's working area, Gianyar district, Bali. The container color was the variable with the highest impact on Aedes aegypti larvae' existence.

The researchers recommend for health workers to apply counseling and training related to MNE-DHF for the community in the Ubud I Health Center's working area. The counseling and training should be done routinely at least once every 6 months to empower the public awareness about the required precautions against dengue vectors in the environment. Furthermore, the researchers recommend for the community itself to observe and avoid larvae' existence by monitoring using a flashlight, water cleaning and draining, and covering water containers tightly. These precautions will eventually prevent creating a favorable breeding environment for Aedes aegypti mosquitoes especially in dark water containers with optimal water $\mathrm{pH}(6.9-8.0)$.

\section{REFERENCES}

Bestari, R. S. and Siahaan, P. P. (2018) 'Hubungan Tingkat Pengetahuan dan Perilaku Mahasiswa Tentang Pemberantasan Sarang Nyamuk (PSN) Demam Berdarah Dengue (DBD) terhadap Keberadaan Jentik Aedes aegypti', Biomedika, 10(1), pp. $\quad 1-5 . \quad$ doi 
https://doi.org/10.23917/biomedika. v10i1.5847.

Budiman, A. (2016) 'Hubungan Keberadaan Jentik Nyamuk dan Perilaku Pemberantasan Sarang Nyamuk Demam Berdarah Dengue (PSN DBD) Masyarakat di Daerah Endemis dan Non Endemis Kecamatan Nanggulan Kabupaten Kulon Progo', IJPH, 11(1), pp. 2839. doi: 10.20473/ijph.v11i1.2016.28-39.

Cahyono, T. (2017) Penyehatan Udara. Yogyakarta: ANDI.

Chandra (2005) Ilmu Kedokteran Pencegahan \& Komunitas. Jakarta: EGC.

Dinata, A. (2018) Bersahabat dengan Nyamuk. Pangandaran: Arda Publishing.

Gafur, A. and Jastam, M. S. (2015) 'Faktor yang Berhubungan dengan Keberadaan Jentik Nyamuk Aedes aegypti di Kelurahan Batua Kota Makassar Tahun 2015', Journal Public Health Science, 7(1), pp. 50-62. doi: https://doi.org/10.24252/as.v7i1.19 77.

Gianyar District Health Office (2017) Profil Kesehatan Kabupaten Gianyar Tahun 2016. Bali: Gianyar District Health Office.

Jacob, A., Pijoh, V. D. and Wahongan, G. J. P. (2014) 'Ketahanan Hidup dan Pertumbuhan Nyamuk Aedes Spp. Pada Berbagai Jenis Air Perindukan', EBM, 2(3), pp. 1-5. doi : 10.35790/ebm.2.3.2014.6039.

Janah, M. and Pawenang, E. T. (2017) 'Karakteristik Sumur Gali dan Keberadaan Jentik Nyamuk Aedes aegypti', Higeia, 1(1), pp. 8-14..

Indonesian Ministry of Health (2001) Pencegahan dan Penanggulangan Penyakit Demam Berdarah Dengue dan Demam Berdarah. Jakarta: Ditjen PPM \& PL. Jakarta.

Indonesian Ministry of Health (2010) Pertemuan Koordinasi Tingkat SR dan SSR Kegiatan Intensifikasi Pengendalian Malaria 6F ATM Malaria. Jakarta: Ditjen PPM \& PL. Jakarta.

Indonesian Ministry of Health (2016) Petunjuk TeknikImplementasi PSN 3M-Plus dengan Gerakan 1 Rumah 1 Jumantik. Jakarta: Kementerian Kesehatan.

Indonesian Ministry of Health (2018) Profil Kesehatan Indonesia Tahun 2017. Jakarta: Kementerian Kesehatan.

Lameshow, S. dan David, W. H. Jr. (1997) Besar : Sampel dalam Penelitian Kesehatan (terjemahan). Yogyakarta: Gadjahmada University Press.

Maftukhah, Azam, M. and Azinar, M. (2017) 'Hubungan Sosiodemografi dan Kondisi Lingkungan dengan Keberadaan Jentik di Desa Mangunjiwan Kecamatan Demak', Jurnal FKM, 11(1), pp. 77-82. doi: http://dx.doi.org/10.12928/kesmas. v11i1.5712.

Malasari (2011) Perbedaan Faktor Perilaku Pemberantasan Sarang Nyamuk dan Lingkungan di Desa Endemis dan Non Endemid DBD (Studi di Wilayah Kerja Puskesmas Ngadiluwih, Kecamatan Ngadiluwih, Kabupaten Kediri). Surabaya: FKM Universitas Airlangga.

Nani (2017) 'Hubungan Perilaku PSN dengan Keberadaan Jentik Aedes aegypti di Pelabuhan Pulang Pisau', Jurnal Berkala Epidemiologi, 5(1), pp. 1-12. doi: 10.20473/jbe.v5i1.2017.1-12.

Nurjana, M. A. and Kurniawan, A. (2017) 'Preferensi Aedes aegypti Meletakkan Telur pada Berbagai Warna Ovitrap di Laboratorium Preferences of Aedes aegypti Lay Eggs in Various Colors Ovitrap in The Laboratory', pp. 37-42. doi: http://doi.org/10.22435/blb.V13i1.

Technical Guidelines for the


Implementation of the 3M-PLus PSN with the Jumantik 1 House 1 Movement (2016). Jakarta: Ministry of Health.

Sumantri, A. H. (2010) Kesehatan Lingkungan. Jakarta: Kencana.

Wijirahayu, S. and Sukesi, T. W. (2019) 'Hubungan Kondisi Lingkungan Fisik dengan Kejadian Demam Berdarah Dengue di Wilayah Kerja Puskesmas Kalasan Kabupaten Sleman', JKLI, 18(1), pp. 19-24. doi: 10.14710/jkli.18.1.19-24.

World Health Organization (2009) Dengue : Guidelines for Diagnosis, Treatment, Prevention, and Controll. Geneva: WHO.

World Health Organization (2011) Prevention and Control of Dengue and Dengue Haemorrhagic Fever (Revised and Expanded Edition). New Delhi: WHO Regional Publication SEARO. 